\title{
HUBUNGAN DUKUNGAN KELUARGA DENGAN KEJADIAN DEPRESI PADA PASIEN DIABETES MELLITUS DI RUMAH SAKIT MUHAMMADIYAH GRESIK
}

\author{
Lilik Supriati ${ }^{\star 凶}$, Tina Handayani Nasution*, Fiqih Andrian Ilmansyah*
}

\begin{abstract}
Abstrak
Diabetes melitus merupakan penyakit gangguan metabolisme karbohidrat, lemak dan protein yang kronis. Penderita diabetes sangat rentan terhadap gangguan psikologis seperti depresi. Salah satu faktor yang mempengaruhi timbulnya depresi pada penderita diabetes mellitus adalah kurangnya dukungan keluarga. Tujuan penelitian ini adalah untuk mengetahui hubungan dukungan keluarga dengan kejadian depresi pada pasien diabetes mellitus di Rumah Sakit Muhammadiyah Gresik. Desain penelitian yang digunakan dalam penelitian ini adalah cross sectional. Sampel dipilih dengan teknik total sampling, dan didapatkan 34 responden penderita DM. Instrumen yang digunakan berupa lembar kuisioner depresi berdasarkan Beck Depression Inventory II (BDI II) dan kuesioner dukungan keluarga. Hasil penelitian menunjukkan bahwa keluarga yang memberikan dukungan "baik" sebanyak 8 responden (24\%), dukungan keluarga "cukup" sebanyak 22 responden (67\%), dan dukungan keluarga "kurang" sebanyak 3 responden $(19 \%)$. Data kejadian depresi pada pasien diabetes mellitus diperoleh 12 responden (38\%) tidak mengalami depresi, dan 22 responden (62\%) mengalami depresi. Analisis data menggunakan uji statistik Spearman rho dengan tingkat kemaknaan $p<0,05$. Hasil uji statistik menunjukkan nilai koefisien korelasi negatif $(r=-0,743)$ dengan nilai $p=0,000$ yang artinya ada hubungan antara dukungan keluarga dengan kejadian depresi pada pasien diabetes mellitus di RS Muhammadiyah Gresik. Kesimpulan dari penelitian ini adalah terdapat hubungan negatif (searah) antara dukungan keluarga terhadap kejadian depresi pada pasien diabetes mellitus. Semakin tinggi dukungan keluarga maka semakin tidak terjadi depresi atau normal, sebaliknya semakin rendah dukungan keluarga maka angka kejadian depresi yang dialami semakin berat.
\end{abstract}

Kata kunci : diabetes mellitus, dukungan keluarga, depresi

\section{CORRELATION BETWEEN FAMILY SUPPORT AND DEPRESSION AMONG PATIENT WITH DIABETES MELLITUS AT MUHAMMADIYAH HOSPITALGRESIK}

\begin{abstract}
Diabetes mellitus is a metabolic disorder involve in chronically impaired of carbohydrate, fat, and protein metabolism. Diabetics are particularly vulnerable to psychological disorder such as depression. One of the factors that affect the incidence of depression in patient with diabetes mellitus is the lack of family support. This study aimed was to determine the relationship between family support and the incident of depression among the diabetes mellitus patients at Muhammadiyah Hospital, Gresik. The research design was crosssectional design. The samples were chose by total sampling technique, and 34 respondents are eligible in this study. The instruments used in this study was depression questioner sheets based on Beck depression inventory II (BDI II) and family support questioner sheets. The result showed that the number of family who delivered the good support were 8 respondents $(24 \%)$, sufficient support were 22 respondents $(67 \%)$, and poor support were 3 respondents (19\%). Data regarding to the incidence of depression indicated that 12 respondents (38\%) did not experienced depression, and 22 respondents (62\%) were experienced depression. Data were analyzed using Spearman rho test with $p<0.05$ in significant level. The statistic analysis showed the negative correlation coefficient $(r=-0.743)$ with $p$ value 0.000 which indicated that there were a relationship between family support and depression in diabetes mellitus patients. Thus, it can be concluded that better family support will reduce depression or become normal, and the poorer family support the more severe patients to experience depression.
\end{abstract}

Keywords : diabetes mellitus, family support, depression

* Program Studi IImu Keperawatan, FKUB

区E-mail: Iylyiex@yahoo.co.id 


\section{Pendahuluan}

Diabetes mellitus (DM) merupakan salah satu masalah kesehatan yang paling serius di abad 21 dan cenderung meningkat pada negara-negara maju.,2 Diperkirakan terdapat 382 juta orang menderita diabetes dan akan meningkat menjadi 592 juta orang pada tahun 2035. Diabetes menyebabkan ,1 juta kematian pada tahun 2013 dan setiap enam detik seseorang meninggal karena diabetes. $^{3}$

Berdasarkan Laporan Tahunan Rumah Sakit Provinsi Jawa Timur tahun 2013 penderita diabetes yang dirawat dirumah sakit umum pemerintah tipe B sebanyak 102.399 kasus. Dan pada rumah sakit tipe $C$ terdapat 35.028 kasus. ${ }^{4}$ Berdasarkan data Dinas Kependudukan jumlah penduduk Kabupaten Gresik sebesar 1.307.995 jiwa, dan dari Dinas Kesehatan Kabupaten Gresik tahun 2010 menunjukkan jumlah penderita diabetes di Kabupaten Gresik sebanyak 14.549 orang.

Menurut Handayani dan Dewi (2009) mengemukakan adanya gangguan psikologis pada orang yang terdiagnosa penyakit diabetes mellitus yaitu depresi, kecemasan, kehilangan minat, mudah marah, dan tersinggung.5Kondisi depresi terjadi akibat faktor fisik dan psikososial yang berhubungan dengan penyakit atau terapinya. Depresi pada diabetes terjadi akibat meningkatnya tekanan pasien yang dialami dari penyakitnya yang kronik.

Penanganan depresi adalah dengan memberikan perhatian dan dukungan yang baik bagi penderita diabetes mellitus. Mengatasi depresi akan lebih mudah dilakukan dengan adanya bantuan dari keluarga, akan tetapi tidak adanya keluarga akan dapat menimbulkan bahkan memperburuk depresi itu sendiri. ${ }^{6}$

Dukungan keluarga sangat penting bagi penderita DM karena keluarga adalah salah satu dasar untuk membantu agar pasien dapat tetap sehat dan meningkatkan adaptasi kehidupan mereka. Dengan dukungan keluarga diharapkan dapat mengurangi risiko untuk terjadinya depresi pada pasien diabetes mellitus. Keluarga berperan sebagai motivator, fasilitator sekaligus sebagai pendamping yang baik dengan begitu penderita DM akan selalu merasa diperhatikan dan diharapkan penderita DM mampu melakukan aktivitas sehari-harinya secara mandiri.

Penelitian ini bertujuan untuk mengetahui hubungan antara dukungan keluarga dengan kejadian depresi pada pasien diabetes mellitus di Rumah Sakit Muhammadiyah Gresik. Penelitian ini diharapkan dapat bermanfaat sebagai bahan masukan dalam memperkaya pengetahuan tentang hubungan dukungan keluarga dengan kejadian depresi pada pasien diabetes mellitus.

\section{Bahan dan Metode}

Penelitian ini dilaksanakan di Rumah Sakit Muhammadiyah Gresik mulai bulan November 2014-Januari2015. Penelitian ini menggunakan studi analitik korelasional dengan pendekatan cross sectional. Penelitian ini bertujuan mencari hubungan dukungan keluarga dengan kejadian depresi pada pasien diabetes mellitus di Rumah Sakit Muhammadiyah Gresik.Populasi dalam penelitian ini adalah semua pasien diabetes mellitus yang dirawat di Rumah Sakit Muhammadiyah Gresik Kabupaten Gresik dengan rata-rata tiap bulan sebanyak 34 orang. Kriteria inklusi yaitu bersedia menjadi responden, penderita diabetes mellitus dengan usia 18-65 tahun, pasien diabetes mellitus yang tinggal satu rumah dengan keluarga. Sebagai kriteria eksklusi yaitu penderita DM tidak kooperatif/menolak untuk dijadikan responden, penderita diabetes mellitus yang tidak memiliki keluarga, Diabetes mellitus dengan komplikasi (gagal ginjal, hipertensi, stroke). 
Variabel independen adalah dukungan keluarga pada pasien diabetes mellitus, sedangkan variabel dependen adalah kejadian depresi pada pasien dengan depresi.

Instrumen yang digunakan adalah kuesioner. Untuk mengukur dukungan keluarga, peneliti menggunakan alat ukur kuesioner pada keluarga yang dikaitkan dengan 4 dukungan keluarga yaitu dukungan emosional, dukungan instrumental, dukungan, penghargaan, dukungan informasi. ${ }^{7}$ Sementara untuk mengukur depresi pada pasien diabetes mellitus digunakan kuesioner berupa Beck depression inventory II. ${ }^{8}$ Skala BDI ॥ merupakan skala pengukuran interval yang mengevaluasi 21 gejala depresi, dua puluh satu item tersebut menggambarkan kesedihan, pesimistik, perasaan gagal, ketidakpuasan, rasa bersalah, harapan akan hukuman, membenci diri sendiri, menuduh diri sendiri, keinginan bunuh diri, menangis, iritabilitas, penarikan diri dari masyarakat, tidak dapat mengambil keputusan, perubahan bentuk tubuh, masalah bekerja, insomnia, kelelahan, anoreksia, kehilangan berat badan, preokupasi somatik, dan penurunan libido.
Pengumpulan data dilakukan dengan cara menyebar kuesioner tertutup (closed ended) kepada responden. Sebelum mengisi kuesioner tersebut, peneliti memberi penjelasan terlebih dahulu agar data yang terkumpul valid dan sesuai dengan harapan peneliti.

Untuk mengetahui hubungan antar variabel, data yang terkumpul disajikan dalam bentuk tabulasi silang antara variabel independen dengan dependen, selanjutnya diuji dengan menggunakan uji Spearmen Rho menggunakan SPSS dengan tingkat kemaknaan $5 \%(p<0,05)$.

\section{Hasil}

Berdasarkan karakteristik responden yang diteliti, pada Gambar 1 ditunjukkan bahwa sebagian besar responden berusia 47-52 tahun yaitu 18 responden (53\%), sedangkan sebagian kecil berusia 59-64 tahun yaitu 5 responden (15\%) dari 34 responden.Pada Gambar 2 ditunjukkan bahwa sebagian besar responden berjenis kelamin laki-laki yaitu 20 responden (59\%) dari 34 responden.

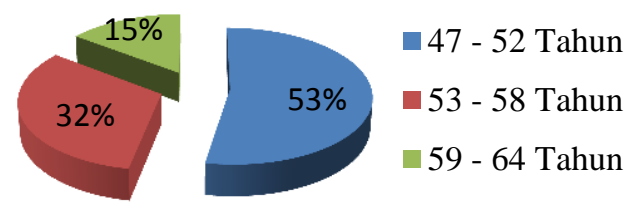

Gambar 1. Persentase jumlah responden pasien DM berdasarkan usia 


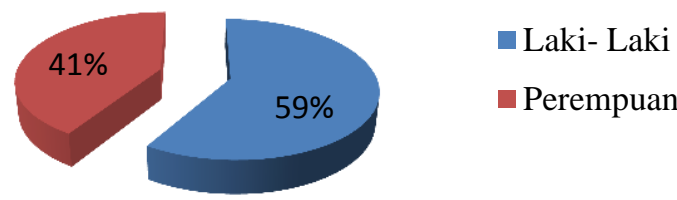

Gambar 2. Persentase jumlah responden pasien DM berdasarkan jenis kelamin

Pada Gambar 3 menunjukkan bahwa hampir setengah responden bekerja sebagai wiraswasta 15 responden (44\%) dan sebagian kecil bekerja sebagai guru yaitu 3 responden $(9 \%)$ dari 34 responden.
Berdasarkan Gambar 4 diketahui bahwa hampir setengah responden berpendidikan SMA yaitu 14 responden (41\%), sedangkan sebagian kecil berpendidikan S1 yaitu 3 responden (12\%) dari 34 responden.

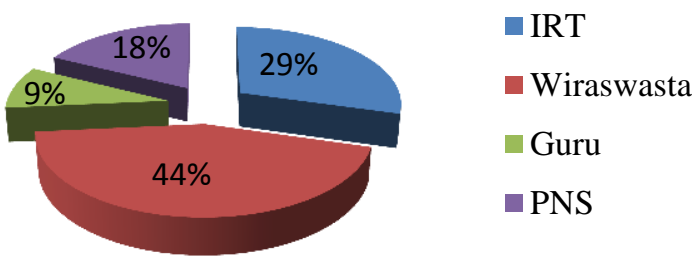

Gambar 3. Persentase jumlah responden pasien DM berdasarkan pekerjaan

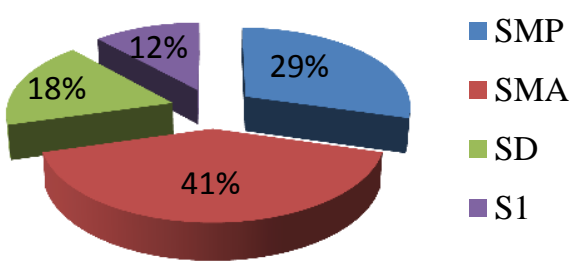

Gambar 4.Persentase jumlahresponden pasien DM berdasarkan pendidikan

Hasil uji statistik tentang dukungan keluarga dan kejadian depresi dapat dilihat pada Tabel 1 dan Tabel 2. 
Tabel 1. Frekuensi responden DM berdasarkan dukungan keluarga

\begin{tabular}{ccc}
\hline $\begin{array}{c}\text { Dukungan } \\
\text { Keluarga }\end{array}$ & Frekuensi & $\begin{array}{c}\text { Persentase } \\
(\%)\end{array}$ \\
\hline Baik & 8 & 24 \\
Cukup & 22 & 67 \\
Kurang & 3 & 19 \\
\hline Total & 34 & 100 \\
\hline
\end{tabular}

Tabel 2. Frekuensi kejadian depresi pada pasien DM

\begin{tabular}{lcc}
\hline \multicolumn{1}{c}{ Kondisi } & Frekuensi & Persentase (\%) \\
\hline Tidak Depresi/ Normal & 12 & 38 \\
Depresi & 22 & 62 \\
\hline Total & 34 & 100 \\
\hline
\end{tabular}

Tabel 3. Analisis statistik terhadap Dukungan keluarga dengan kejadian depresi pada pasien DM

\begin{tabular}{|c|c|c|c|c|c|c|c|}
\hline \multirow[t]{3}{*}{ Dukungan Keluarga } & & \multicolumn{6}{|c|}{ Depresi } \\
\hline & \multicolumn{2}{|c|}{$\mathrm{Ya}$} & \multicolumn{2}{|c|}{ Tidak } & \multirow[t]{2}{*}{ Total } & \multirow{2}{*}{$\begin{array}{c}r \\
-0,743\end{array}$} & \multirow{2}{*}{$\begin{array}{c}\text { p_value } \\
0,000\end{array}$} \\
\hline & (f) & $(\%)$ & (f) & $(\%)$ & & & \\
\hline Baik & 1 & 11 & 8 & 89 & 9 & & \\
\hline Cukup & 18 & 82 & 4 & 18 & 22 & & \\
\hline Kurang & 3 & 100 & 0 & 0 & 3 & & \\
\hline Total & & 2 & & 3 & 34 & & \\
\hline
\end{tabular}

Pada tabel 3,diketahui bahwa dari 9 pasien diabetes mellitus yang memiliki dukungan keluarga baik, didapatkan hasil 8 orang $(89 \%)$ tidak depresi atau normal, dan sebagian mengalami depresi ringan yaitu sebanyak 1 orang (11\%), dari 22 pasien DM yang memiliki dukungan keluarga cukup, didapatkan hasil 4 orang (18\%) tidak depresi atau normal, dan hampir sebagian mengalami depresi ringan sebanyak 12 orang $(55 \%)$ dan pasien DM yang memiliki dukungan keluarga kurang semuanya mengalami depresi berat sebanyak 3 responden $(100 \%)$.
Berdasarkan hasil uji statistik Spearman rho, diperoleh nilai koefisien korelasi negatif sebesar $r=-0,743$. Nilai korelasi Spearman rho ini memiliki nilai signifikansi sebesar $0,000(p<0,05)$ sehingga dapat disimpulkan bahwa terdapat hubungan yang signifikan dengan arah negatif antara dukungan keluarga dengan kejadian depresi pada pasien diabetes mellitus.

\section{Pembahasan}

Berdasarkan hasil di atas diketahui distribusi usia responden pasien diabetes mellitus yang dirawat di Rumah Sakit 
Muhammadiyah Gresik, yang terbanyak yaitu usia 47-52 tahun sebanyak 18 responden $(53 \%)$ dan usia tersedikit 59-64 tahun dengan 5 responden (15\%). Tahapan dewasa dibagi menjadi tiga tahap, yaitu dewasa awal, dewasa menengah, dan dewasa akhir. Dewasa awal dimulai sejak seseorang berusia 21 atau 22 tahun sampai 35 tahun. Masa dewasa awal ditandai dengan usia yang produktif, masa komitmen, masa perubahan nilai, masa penyesuaian diri dengan cara hidup, dan masa kreatif. Dewasa menengah dimulai dari usia 36 sampai 45 tahun yang ditandai dengan masa pencapaian sukses seseorang, masa berprestasi, dan masa transisi. Kemudian, dewasa akhir dimulai dari usia 46 sampai 60 tahun yang ditandai dengan penurunan kondisi fisik dan masalah kesehatan.

Hasil penelitian menunjukkan laki-laki lebih banyak menjadi pasien DM yang menjalani perawatan di RS Muhammadiyah Gresik. Hal ini karena sebagian besar lakilaki menjalani pola hidup yang tidak sehat, sehingga dapat menyebabkan laki-laki lebih banyak terkena DM dibandingkan dengan perempuan. Keadaan ini diduga karena berkaitan dengan distribusi lemak. Pria cenderung menyimpan lebih banyak lemak di sekitar perut dan jantung, selain itu penumpukan lemak terkonsentrasi di sekitar perut sehingga memicu obesitas sentral yang lebih berisiko memicu gangguan metabolism. Ditambah adanya bukti yang menunjukkan bahwa sebagian besar penderita DM berjenis kelamin laki-laki yang melakukan perawatan di RS Muhammadiyah Gresik memiliki berat badan yang tidak ideal (kelebihan berat badan) sehingga dengan mudah terkena DM.

Berdasarkan hasil penelitian tentang kejadian depresi, diketahui bahwa responden di RS Muhammadiyah Gresik yang mengalami depresi sebanyak 22 responden (62\%) dan untuk yang tidak depresi atau normal sebanyak 12 responden $(38 \%)$. Kebanyakan pasien DM mengalami depresi ringan dan depresi sedang, namun keluarga memberikan dukungan adekuat secara emosional untuk meningkatkan harga diri pasien DM dari perasaan sedih, murung, serta tidak bahagia dalam menjalani hidupnya. Pasien yang mengalami depresi berat terutama karena masalah fisik yang belum teratasi seperti penyakit DM yang diderita selama bertahun-tahun sehingga tingkat depresi semakin tinggi. Banyak orang berasumsi bahwa penyakit DM adalah penyakit yang tidak dapat disembuhkan, hidup sengsara karena terbebani penyakit tersebut membuat stres menjadi lebih tinggi. Sehingga tidak jarang penderita diabetes mellitus putus asa dalam menjalani kehidupannya.

Ditinjau dari tingkat pendidikan, kebanyakan pasien DM berpendidikan rendah sehingga lebih mudah mengalami depresi daripada pasien DM yang berpendidikan menengah atau tinggi. Pada penelitian sebelumnya dinyatakan bahwa pendidikan rendah merupakan faktor risiko depresi pada pasien yang memiliki penyakit kronis. Hal itu karena kurangnya pajanan informasi mengenai pola pengambilan koping stres yang tepat agar terhindar dari depresi.

Kebanyakan pasien DM memiliki pekerjaan wiraswasta yang berakibat pada terjadinya depresi tingkat sedang. Hal ini karena tingkat persaingan kerja sangat tinggi dan lapangan pekerjaan kurang memadai serta tunjangan gaji yang kurang. Dengan demikian untuk memenuhi kebutuhan ekonomi keluarga sehari-hari kurang dari cukup. Faktor tersebut dapat memicu keadaan stres yang berlebihan dan bermanifestasi kepada depresi.

Depresi dapat juga terjadi akibat faktor psikologis dan psikososial yang berhubungan dengan penyakit atau terapinya. Depresi pada pasien DM terjadi karena meningkatnya tekanan akibat penyakitnya yang kronik. Depresi lebih banyak dijumpai pada perempuan, ras minoritas, tidak menikah, umur pertengahan, status sosial ekonomi rendah dan tidak 
bekerja. ${ }^{9}$ Depresi juga dapat disebabkan oleh faktor biologi, genetik, dan psikososial yang saling mempengaruhi satu dengan yang lainnya. ${ }^{10}$

Kejadian depresi pada pasien diabetes mellitus terbanyak pada kategori depresi sedang. Diharapkan dengan adanya dukungan keluarga, orang lain dan lingkungan sekitar dapat menurunkan atau mengurangi angka kejadian depresi pada pasien diabetes mellitus. Dengan demikian pasien DM bisa menjalani hidup lebih optimal lagi dibandingkan sebelumnya.

\section{Kesimpulan}

Hasil penelitian ini menyimpulkan bahwa terdapat hubungan antara dukungan keluarga dengan kejadian depresi pada pasien diabetes mellitus di RS Muhammadiyah Gresik. Dengan demikian dapat dibuktikan bahwa dukungan keluarga mempunyai peranan penting dalam mencegah terjadinya depresi pada penderita diabetes mellitus.

\section{Saran}

Dengan mengetahui hasil penelitian ini diharapkan bagi pelayanan kesehatan dapat memberikan informasi seperti khususnya pada keluarga tentang pentingnya dukungan keluarga untuk kesehatan penderita diabetes mellitus terutama kesehatan psikologinya. Diharapkan ada penelitian selanjutnya mengenai bagaimana dukungan keluarga yang baik sehingga dapat menurunkan timbulnya depresi pada pasien diabetes mellitus.

\section{Daftar Pustaka}

1. Tellechea A et al. Increased Skin Inflammation and Blood Vessel Density in Human and Experimental Diabetes. Int J Low Extrem Wound. 2010; 12:4-11.

2. Donath et al. Type 2 Diabetes as an Inflammatory Disease. Nature Reviews
Immunology. 2003; 11:98-107. doi:10.1038/nri2925.

3. International Diabetes Federation. Weight loss surgery reduces diabetes risk. (Online). 2013.www.idf.org.Diakses 19 September 2014.

4. (DINKES) Dinas Kesehatan Provinsi Jawa Timur. Profil Dinas Kesehatan Jawa Timur 2012.2013.

5. Handayani dan Dewi. Analisis Kualitas Hidup Penderita dan Keluarga Pasca Serangan Depresi. Psycho Idea. 2009; 7(1):35-44.

6. Wilkinson. Stress. Jakarta: Dian Rakyat.2002.

7. Friedman M, Marilyn. Keperawatan Keluarga: Teori dan Praktik. Jakarta: EGC. 1998.

8. Beck AT. Depression: Causes and Treatment. Philadelphia: University of Pensylvania Press.1987.

9. Kebeh L. Perbedaan Tingkat Depresi Pada Pasien Diabetes Mellitus Tipe 2 Obese dan Non-Obese di RSUD $d r$. Moewardi Solo. (Online).2011. http://digilib.uns.ac.id/.

10. Tarigan. Perbedaan Depresi pada Pasien Dyspepsia Fungsional dan Dyspepsia Organik. Medan: USU Library.2003. 